\title{
Pengembangan Media Pembelajaran Interaktif Android Matematika dengan Pendekatan STEM pada Materi Trigonometri
}

\author{
Almas Zati Hulwani ${ }^{1}$, Heni Pujiastuti ${ }^{2}$, Isna Rafianti ${ }^{3}$ \\ 1, 2 Program Studi Pendidikan Matematika, Fakultas Ilmu Pendidikan, Universitas Sultan Ageng Tirtayasa, \\ Jl. Raya Jakarta KM.4, Panancangan, Kec. Serang, Kota Serang, Banten, Indonesia \\ almaszatihulwani98@gmail.com
}

\begin{abstract}
This research is motivated by the development of technology and information to improve the quality of education. Learning in schools tends to be passive because teachers use the lecture method when teaching so that students are not active in learning activities, the 2013 curriculum demands a change from teacher centered to student centered. To create an active and interactive learning situation, develop interactive learning media using an android application with a STEM approach on trigonometry material. The purpose of this study was to develop an interactive learning media for android mathematics with a STEM approach on trigonometric material that is valid, practical, and has a potential effect on student responses. This research is a development research or development design research type of formative research. This research consists of two stages, namely a preliminary study and a formative study, with a formative evaluation design flow. The subjects of this study were students of class X MIPA at one of the SMA Negeri Serang City. Based on the results of the study, it was found that the development of interactive learning media android mathematics with a STEM approach on trigonometry material was feasible to use in learning activities based on validity, practicality, and potential effects tests. The validity test was obtained at the expert review stage, the practicality test was obtained at the one-to-one and small group stages, and the potential effect on student responses was obtained at the field test stage.
\end{abstract}

Keywords: Learning Media, Interactive, Android, STEM, Trigonometry

\begin{abstract}
Abstrak
Penelitian ini dilatarbelakangi oleh perkembangan teknologi dan informasi untuk meningkatkan mutu pendidikan. Pembelajaran di sekolah cendrung pasif dikarenakan guru menggunakan metode ceramah saat mengajar sehingga siswa tidak aktif dalam kegiatan pembelajaran, kurikulum 2013 menuntut adanya perubahan dari teacher centered menuju student centered. Untuk menciptakan situasi pembelajaran yang aktif dan interaktif peneliti mengembangkan media pembelajaran interaktif dengan menggunakan aplikasi android dengan pendekatan STEM pada materi trigonometri. Tujuan penelitian ini adalah mengembangkan media pembelajaan interaktif android matematika dengan pendekatan STEM pada materi trigonometri yang valid, praktis dan memiliki efek potensial terhadap respon siswa. Penelitian ini merupakan penelitian pengembangan atau development design research tipe formative research. Penelitian ini terdiri dari dua tahap yaitu preliminary study dan formative study, dengan alur desain formative evaluation. Subjek penelitian ini adalah siswa kelas X MIPA di salah satu SMA Negeri Kota Serang. Berdasarkan hasil penelitian diperoleh bahwa pengembangan media pembelajaran interaktif android matematika dengan pendekatan STEM pada materi trigonometri layak digunakan dalam kegiatan pembelajaran berdasarkan uji validitas, kepraktisan dan efek potensial. Uji validitas didapatkan pada tahap expert review, uji kepraktisan didapatkan pada tahap one-to-one dan small group, dan efek potensial tehadap respon siswa didapatkan pada tahap field test.
\end{abstract}

Kata kunci: Media Pembelajaran, Interaktif, Android, STEM, Trigonometri

Copyright (c) 2021 Almas Zati Hulwani, Heni Pujiastuti, Isna Rafianti

$\triangle$ Corresponding author: Almas Zati Hulwani

Email Address: almaszatihulwani98@gmail.com (Jl. Raya Jakarta KM.4, Panancangan, Banten, Indonesia)

Received 18 June 2021, Accepted 30 June 2021, Published 02 August 2021

\section{PENDAHULUAN}

Kemajuan teknologi adalah sesuatu yang tidak bisa dihindari dalam kehidupan ini, karena kemajuan teknologi berjalan sesuai dengan kemajuan ilmu pengetahuan. Setiap inovasi diciptakan untuk memberikan manfaat positif bagi kehidupan manusia. Teknologi juga memberikan banyak kemudahan, serta sebagai cara baru dalam melakukan aktivitas manusia. Manusia juga sudah menikmati banyak manfaat yang dibawa oleh inovasi-inovasi teknologi yang telah dihasilkan dalam dekade terakhir ini. Pada era modern ini, 
perkembangan teknologi dan informasi sudah sangat berkembang dengan pesat dan tidak bisa dihindari lagi pengaruhnya terhadap dunia pendidikan, baik itu pengaruh yang positif ataupun pengaruh yang negatif, sehingga menuntut dunia pendidikan untuk senantiasa menyesuaikan dengan perkembangan teknologi terhadap upaya peningkatan mutu pendidikan, terutama dalam hal memanfaatkan penggunaan teknologi dan informasi bagi dunia pendidikan khususnya dalam proses belajar mengajar. Menurut Akhmadan (2017) salah satu cara penggunaan teknologi dalam pembelajaran yaitu pemanfaatan sumber daya teknologi sebagai media dalam proses pembelajaran.

Media pembelajaran bisa dikatakan sebagai hal yang penting dalam berlangsungnya proses pembelajaran. Media pembelajaran dapat membantu guru dalam penyampaian materi, membuat materimateri yang abstrak menjadi lebih konkrit, serta materi yang rumit menjadi mudah untuk dipahami. Sanjaya (2010) menegaskan seorang guru perlu memiliki kemampuan merancang dan mengimplementasikan berbagai strategi pembelajaran yang dianggap cocok dengan minat dan bakat serta sesuai dengan taraf perkembangan siswa, termasuk didalamnya memanfaatkan berbagai sumber dan media pembelajaran untuk menjamin efektivitas pembelajaran. Sebuah penelitian yang dilakukan oleh Herawati (2017) menyatakan bahwa pemakaian media pembelajaran dapat membangkitkan keinginan dan minat yang baru, membangkitkan motivasi, dan rangsangan kegiatan belajar, dan membawa pengaruh-pengaruh psikologis terhadap siswa, dapat disimpulkan adanya keterkaitan antara media pembelajaran dan teknologi dimana sama-sama memiliki daya tarik.

Media pembelajaran mulai berkembang pesat, khususnya media pembelajaran berbasis teknologi. Berbagai media pembelajaran mulai dikemas secara modern dan unik, baik dalam bentuk perangkat keras seperti buku saku, lembar kerja siswa ataupun perangkat lunak seperti Android Studio dan aplikasi untuk komputer dan ponsel yang dikemas dalam bentuk interaktif. Media pembelajaran interaktif ini kerap kali menjadikan kesukaan bagi siswa Indonesia, seperti hasil penelitian yang dilakukan oleh Zakiy, Muhammad, \& Farida (2018) yang berjudul "Pengembangan Media Android dalam Pembelajaran Matematika" mendapatkan hasil bahwa media pembelajaran matematika berbasis android berdasarkan respon siswa, siswa sangat antusias dan sangat menarik dengan hadirnya media pembelajaran matematika android.

Dengan berkembangnya teknologi saat ini perlu adanya media pembelajaran yang bersifat mandiri dan membuat pembelajaran lebih menarik. Salah satunya media pembelajaran berbasis android, menurut Juraman (2014) bahwa saat ini banyak masyarakat yang beralih menggunakan perangkat berbasis android untuk dijadikan sebagai media dalam mengakses informasi secara mudah dan cepat. Hasil penelitian yang dilakukan oleh Lu 'mu (2017) menyatakan bahwa aplikasi media pembelajaran menggunakan smartphone berbasis android terbukti layak, praktis, dan efisien untuk digunakan dalam pembelajaran.

Oleh karena itu perlu adanya pengembangan media pembelajaran modern dalam bentuk perangkat lunak (software) dalam ponsel yang digunakan oleh siswa kapan dan dimana pun. Perangkat lunak yang digunakan yaitu Android Studio, Maiyana (2018) menyatakan Android studio direkomendasikan Integrated Development Environment (IDE) untuk mengembangkan aplikasi android, aplikasi ini dipublikasikan oleh Google pada tanggal 16 mei 2013 dan tersedia secara gratis dibawah lisensi Apache 2.0. Sejak saat itu, 
Android Studio mengantikan Eclipse sebagai IDE resmi untuk mengembangkan aplikasi android. Dengan adanya media pembelajaran menggunakan Android Studio yang ditampilkan di smartphone diharapkan dapat meningkatkan antusias, minat dan hasil pembelajaran siswa.

Di masa mendatang, Indonesia perlu meningkatkan kemampuan kompetitif agar bisa bersaing secara global, baik dalam penguasaan ilmu pengetahuan ataupun teknologi. Hal inilah menjadi alasan dibutuhkannya pengembangan kegiatan pembelajaran yang dapat mencakup (Science, Technology, Engineering, and Mathematics) yang biasa disingkat dengan sebutan STEM. Pendidikan berbasis STEM saat ini menjadi alternatif pembelajaran sains yang dapat membangun generasi agar mampu menghadapi abad 21 yang penuh dengan tantangan untuk kemajuan di masa depan. Pendidikan sains, teknologi, teknik, dan matematika (STEM) menurut Bybee (2010) adalah pendekatan terintegrasi yang mengajarkan teknologi dan teknik berbasis sains dan matematika di taman kanak-kanak hingga kelas 12. Sejalan dengan LaboyRush (2010) program integrasi STEM (Science, Technology, Engineering, and Mathematics) dalam pembelajaran merupakan program pembelajaran yang menggabungkan dua atau lebih bidang ilmu yang termuat dalam STEM yaitu sains, teknologi, teknik atau rekayasa, dan matematika. Aplikasi android dengan pendekatan STEM ini menggunakan model pembelajaran Project Based Learning (PjBL). Kemendikbud (2017) menyatakan bahwa Project Based Learning (PjBL) adalah suatu model pembelajaran yang menggunakan suatu proyek dalam proses pembelajaran, dan berpusat pada siswa (Student centered). Model PjBL memberikan kebebasan kepada para siswa untuk merencanakan aktivitas belajar mereka, melaksanakan proyek secara kolaboratif, dan pada akhirnya menghasilkan produk kerja yang dapat dipresentasikan kepada orang lain. Hasil penelitian yang dilakukan oleh Erlinawati, Bektiarso, \& Maryani (2019) menyatakan bahwa siswa menjadi lebih aktif dalam kegiatan pembelajaran dan siswa dapat mengeksplor pengetahuannya dengan menggunakan model pembelajaran Project Based Learning (PjBL) berbasis STEM sehingga siswa dapat bersaing di era perkembangan teknologi di abad 21.

May \& Courtney (2016) menyatakan bahwa trigonometri merupakan komponen penting dari kurikulum matematika Sekolah Menengah Atas (SMA), matematika dan sains, serta bidang ilmu lain yang merupakan topik yang sulit dipelajari baik oleh siswa ataupun oleh guru. Pemilihan materi trigonometri dengan alasan bahwa selama ini siswa sering hanya melakukan perhitungan trigonometri yang sesuai dengan rumus yang diberikan saja tanpa mengerti tentang manfaat atau kegunaan trigonometri tersebut dalam kehidupan sehari-hari dan juga materi trigonometri bisa dimanfaatkan dalam pendekatan STEM. Hal ini berarti dengan pendekatan STEM siswa tidak hanya sekedar menghafal konsep saja, tetapi lebih kepada bagaimana siswa mengerti dan memahami konsep-konsep sains dan kaitannya dalam kehidupan sehari-hari. Oleh karena itu peneliti mencoba mengembangkan media pembelajaran interaktif android matematika dengan pendekatan STEM pada materi trigonometri.

\section{METODE}

Penelitian dilakukan di salah satu Sekolah Menengah Atas kelas X, subjek penelitian ini adalah 35 siswa kelas X MIPA 7 SMA Negeri 2 Kota Serang. Penelitian ini merupakan penelitian pengembangan atau 
development design research tipe formative research. Menurut Tessemer (1993) terdapat dua tahap dalam penelitian ini yaitu preliminary study (tahap persiapan dan tahap pengembangan) dan tahap formative study (tahap evaluasi dan revisi). Berikut merupakan langkah-langkah pada tahap formative study.

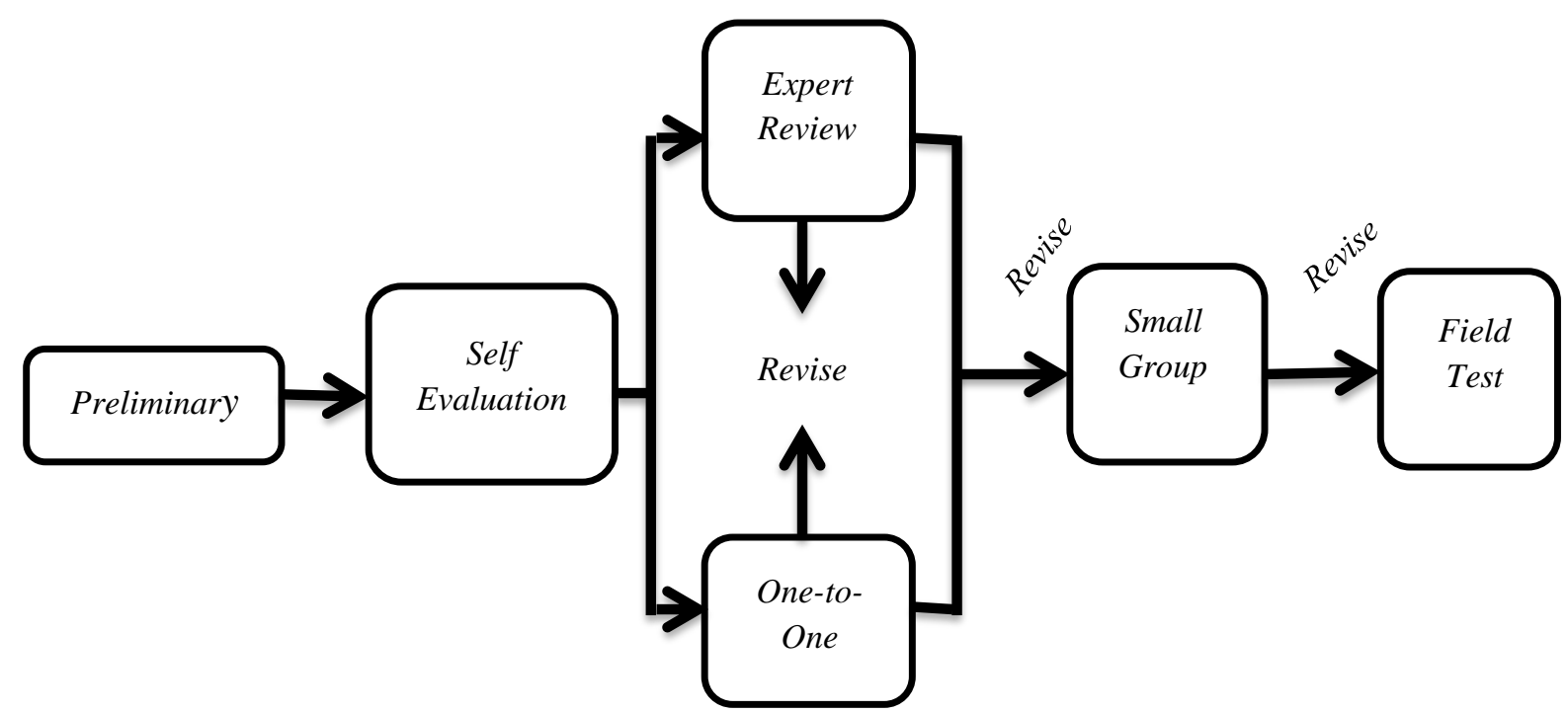

Gambar 1. Alur Desain Formative Evaluation (Tessemer, 1993) dan (Zulkardi, 2006)

Pada tahap preliminary study, tahap ini terdiri dari dua tahap penelitian yaitu tahap perencanaan dan tahap pengembangan. Pada tahap perencanaan, peneliti melakukan penentuan tempat dan subjek penelitian, dalam hal ini peneliti membuat surat penelitian kesekolah dan setelah di izinkan pihak sekolah. Peneliti menghubungi guru mata pelajaran matematika di SMA Negeri 2 Kota Serang dan mengatur jadwal penelitian dengan guru kelas dan prosedur yang dilaksanakan dengan guru kelas yang dijadikan tempat penelitian dan menganalisis kelas. Selanjutnya peneliti melakukan analisis kebutuhan dengan menganalisis kurikulum 2013 untuk mengidentifikasi kompetensi dasar, capaian pembelajaran, indikator pembelajaran dan materi yang dimuat pada media pembelajaran yang di kembangkan pada media pembelajaran interaktif android matematika dengan pendekatan STEM pada materi trigonometri. Berdasarkan hasil analisis kebutuhan, peneliti melanjutkan ke tahap perumusan tujuan pembelajaran sehingga didapatlah indikator dan tujuan pembelajaran yang dicapai. Tahap pengembangan merupakan tahap merancang dan mendesain produk awal. Pada tahap pengembangan ini peneliti mengembangkan topik, menyusun draf dan memproduksi prototype 1.

Pada tahap formative study, peneliti menggunakan alur desain formative evaluation. Tahap pertama yang dilakukan adalah self evaluation dimana peneliti melakukan evaluasi dan menilai sendiri terhadap desain media pembelajaran yang dikembangkan pada prototype 1 . Peneliti melakukan pengecekan dengan menilai atau mengevaluasi terhadap desain aplikasi, kompetensi inti, kompetensi dasar, indikator, tujuan pembelajaran, materi trigonometri, langkah-langkah dari STEM pada Lembar Kerja Peserta Didik (LKPD) yang terdapat pada media pembelajaran dengan karakteristik dari STEM-PjBL, kuis, petunjuk penggunaan serta tombol/ikon pada aplikasi, informasi. Hal ini dilakukan guna meminimalisir kekurangan prototipe 1 sebelum dilakukan penilaian ke tahap expert review dan one-to-one. Pada tahap expert review, prototype 1 
yang telah dikembangkan pada tahap self evaluation diberikan kepada ahli media dan ahli pendidikan untuk menilai dan memberikan saran serta komentarnya terkait kelayakan isi, kebahasaan, dan desain dari prototipe 1 dengan mengisi lembar validasi yang telah disusun peneliti. Hasil dari validasi ahli dijadikan acuan untuk merevisi prototipe 1 sehingga prototipe 1 dinyatakan valid dan layak untuk digunakan. Pada tahap one-to-one, peneliti bersamaan dengan validasi ahli media dan ahli pendidikan untuk menguji kepraktisan prototipe 1. Peneliti meminta tiga orang siswa untuk menilai prototipe 1 yang sudah dikembangkan dengan mengisi lembar angket untuk mengetahui tanggapan berupa komentar dan saran mereka terhadap prototipe 1. Setelah dilakukan analisis berdasarkan hasil expert review dan one-to-one, maka dilakukan revisi pada prototipe 1 sehingga dihasilkan prototipe 2 yang valid dan praktis.

Pada tahap small group prototype 2 diberikan kepada kelompok kecil yang berjumlah 6 siswa, dengan mengisi lembar angket untuk mengetahui tanggapan berupa komentar dan saran siswa terhadap prototipe 2 . Instrumen angket yang digunakan dalam tahap ini sama dengan instrumen angket pada tahap one-to-one, tahap small group ini untuk menguji tingkat kepraktisan prototipe 2. Berdasarkan hasil observasi dan hasil angket tanggapan siswa, selanjutnya prototipe 2 direvisi kembali sehingga dihasilkan prototipe 3 . Setelah diperoleh prototype 3 yang valid dan praktis, maka dilakukan uji coba field test pada subjek penelitian untuk melihat efek potensial dari media pembelajaran yang dikembangkan oleh peneliti terhadap respon siswa. Berikut merupakan prosedur penelitian pengembangan media pembelajaran interaktif android matematika dengan pendekatan STEM pada materi trigonometri.

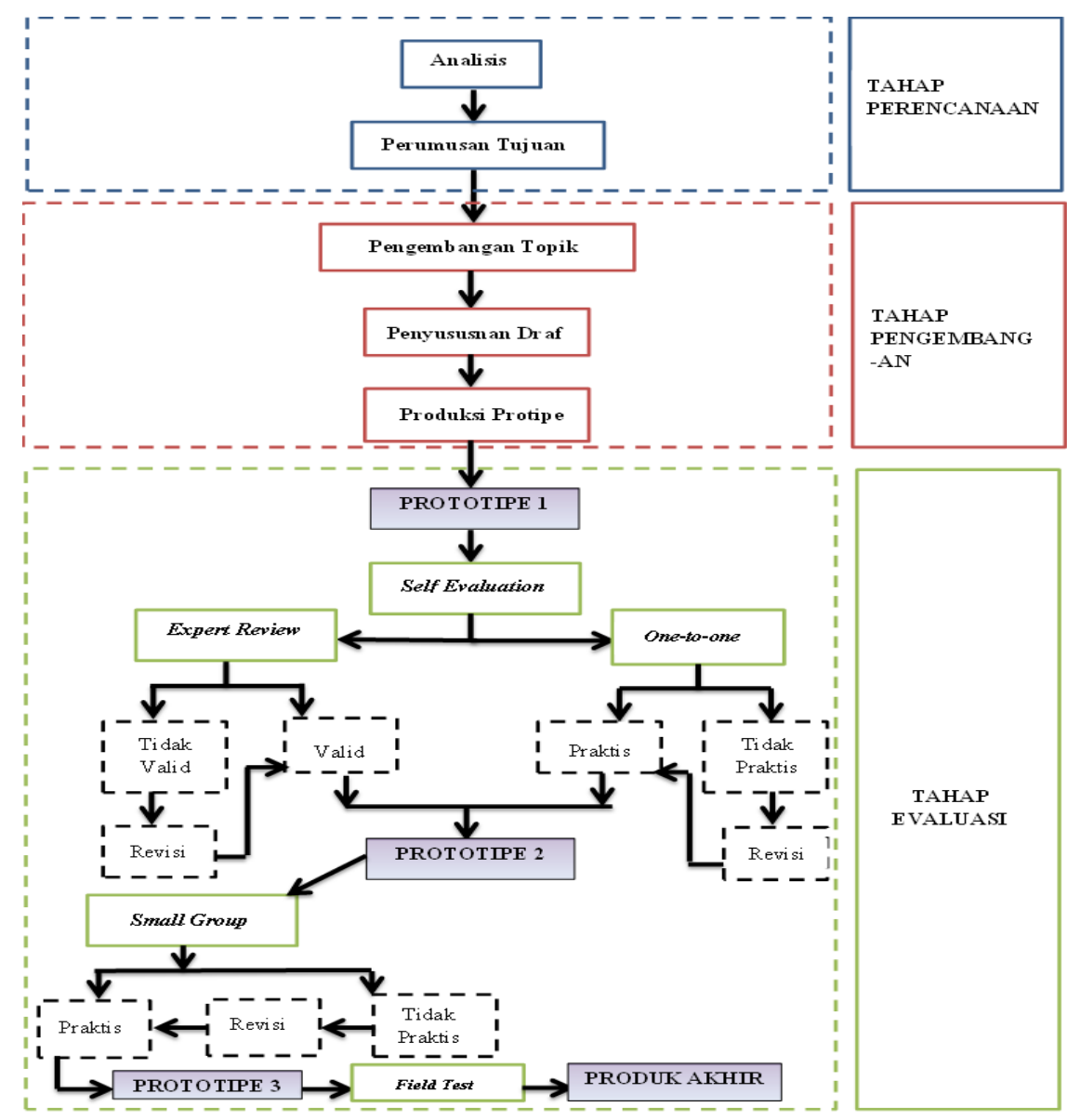

Gambar 2. Alur Prosedur Penelitian 
Riduwan (2013) berpendapat bahwa instrumen penelitian merupakan alat bantu peneliti dalam pengumpulan data, mutu instrument menentukan mutu data yang dikumpulkan, sehingga tepatlah dikatakan bahwa hubungan instrumen dengan data adalah sebagai jantungnya penelitian yang saling terkait. Teknik pengumpulan data dalam penelitian ini adalah angket atau kuesioner. Widoyoko (2016) menyatakan bahwa angket atau kuesioner merupakan metode pengumpulan data yang dilakukan dengan cara memberi seperangkat pernyataan atau pertanyaan tertulis kepada responden untuk diberikan respon sesuai dengan permintaan pengguna. Angket dalam penelitian yang digunakan untuk mendapatkan data kevalidan, data kepraktisan dan data efektifitas media didapat dari uji ahli media dan uji ahli pendidikan sebagai uji kevalidan, respon siswa sebagai uji kepraktisan, dan respon siswa untuk melihat efek potensial dari media pembelajaran interaktif android matematika yang dikembangkan oleh peneliti.

Pada penelitian ini terdapat tiga macam analisis data yaitu analisis data kevalidan yang diperoleh dari pengisian angket para ahli media dan ahli pendidikan pada tahap expert review, analisis data kepraktisan yang diperoleh dari pengisian angket tahap one-to-one dan small group, dan analisis data efek potensial yang didapat dari pengisian angket respon siswa pada tahap field test. Data tersebut kemudian dianalisis untuk menentukan kevalidan, kepraktisan dan melihat efek potensial media pembelajaran interaktif android matematika dengan pendekatan STEM pada materi trigonometri.

\section{HASIL DAN DISKUSI}

\section{Hasil}

Berdasarkan prosedur penelitian pengembangan ada beberapa tahapan yang dilakukan. Tahapantahapan yang dilalui dalam penelitian pengembangan media pembelajaran interaktif android matematika dengan pendekatan STEM pada materi trigonometri adalah sebagai berikut:

\section{Tahap Preliminary Study (Tahap Persiapan dan Tahap Pengembangan)}

Pada tahap perencanaan ini diawali dengan penentuan tempat dan subjek penelitian, mengatur jadwal penelitian, dan menganalisis kebutuhan dengan menganalisis kurikulum 2013. Selanjutnya tahap yang dilakukan peneliti untuk merancang dan mendesain produk awal, yaitu dimulai dari pengembangan topik, penyusunan draf dan membuat prototype 1 . Topik yang dikembangkan yaitu materi trigonometri yang disesuaikan dengan buku mata pelajaran matematika kurikulum 2013 edisi revisi 2017. Peneliti melakukan penyusunan draf dengan menentukan komponen-komponen yang dituliskan dalam prototype 1 media pembelajaran karena media pembelajaran yang dikembangkan berupa software yaitu Android Studio. Berikut merupakan komponen-komponen pada prototype 1:

Tabel 1. Komponen-komponen Prototype 1 dalam Android Studio

\begin{tabular}{|c|l|l|}
\hline No. & Komponen Android Studio & \multicolumn{1}{c|}{ Penjelasan } \\
\hline 1. & Cover Android Studio & $\begin{array}{l}\text { Memuat judul android studio, gambar yang berkaitan dengan } \\
\text { materi, tombol musik, tombol untuk memasuki halaman } \\
\text { selanjutnya yaitu home, dan tombol keluar dari aplikasi Android } \\
\text { Studio. }\end{array}$ \\
\hline 2. & Home & Berisi tombol yang memuat kompetensi, materi trigonometri, \\
\hline
\end{tabular}




\begin{tabular}{|c|l|l|}
\hline & & $\begin{array}{l}\text { Lembar Kerja Peserta Didik (LKPD), evaluasi, petunjuk, dan } \\
\text { informasi. }\end{array}$ \\
\hline 3. & Petunjuk & $\begin{array}{l}\text { Berisi petunjuk aplikasi yaitu petunjuk penggunaan dan } \\
\text { petunjuk tombol dalam aplikasi Android Studio ini. }\end{array}$ \\
\hline 4. & Informasi & Memuat profil nama pembimbing dan tentang STEM. \\
\hline 5. & Kompetensi & $\begin{array}{l}\text { Berisi kompentensi inti, kompetensi dasar, indikator, dan tujuan } \\
\text { pembelajaran trigonometri. }\end{array}$ \\
\hline 6. & Materi & $\begin{array}{l}\text { Memuat materi trigonometri yang mempunyai beberapa sub } \\
\text { materi, yang dibahas yaitu perbandingan trigonometri pada } \\
\text { segitiga siku-siku, perbandingan trigonometri pada segitiga } \\
\text { siku-siku untuk sudut istimewa dan aturan sinus dan cosinus. }\end{array}$ \\
\hline 7. & $\begin{array}{l}\text { Lembar Kerja Peserta Didik } \\
\text { (LKPD) }\end{array}$ & $\begin{array}{l}\text { Terdapat LKPD-PjBL dan siswa dapat share dan download } \\
\text { LKPD tersebut. }\end{array}$ \\
\hline 8. & Kuis & $\begin{array}{l}\text { Terdapat kuis yang memuat soal trigonometri dengan } \\
\text { pendekatan STEM. }\end{array}$ \\
\hline
\end{tabular}

Selanjutnya hasil penyusunan draf yang telah dilakukan, peneliti memulai produksi dan mendesain prototype 1 media pembelajaran sesuai dengan komponen-komponen dalam Android Studio dengan menambahkan background, elemen atau ikon, dan tombol sesuai dengan materi trigonometri dengan pendekatan STEM, teks yang rapih dan berwarna, tabel yang diatur dan disesuaikan dengan teks sehingga tampilan setiap halaman tersusun dengan rapih dan menarik. Peneliti merancang hasil desain background materi trigonometri dengan pendekatan STEM, Lembar Kerja Peserta Didik (LKPD) yang berisikan komponen-komponen pembelajaran STEM dengan model pembelajaran PjBL, soal kuis dan media pembelajaran interaktif android matematika yang dikembangkan pada Android Studio agar relevan dengan pelaksanaan pembelajaran STEM (Science, Technology, Engineering, Mathematics). Berikut merupakan desain awal yang sudah dikembangkan pada Gambar 3 .
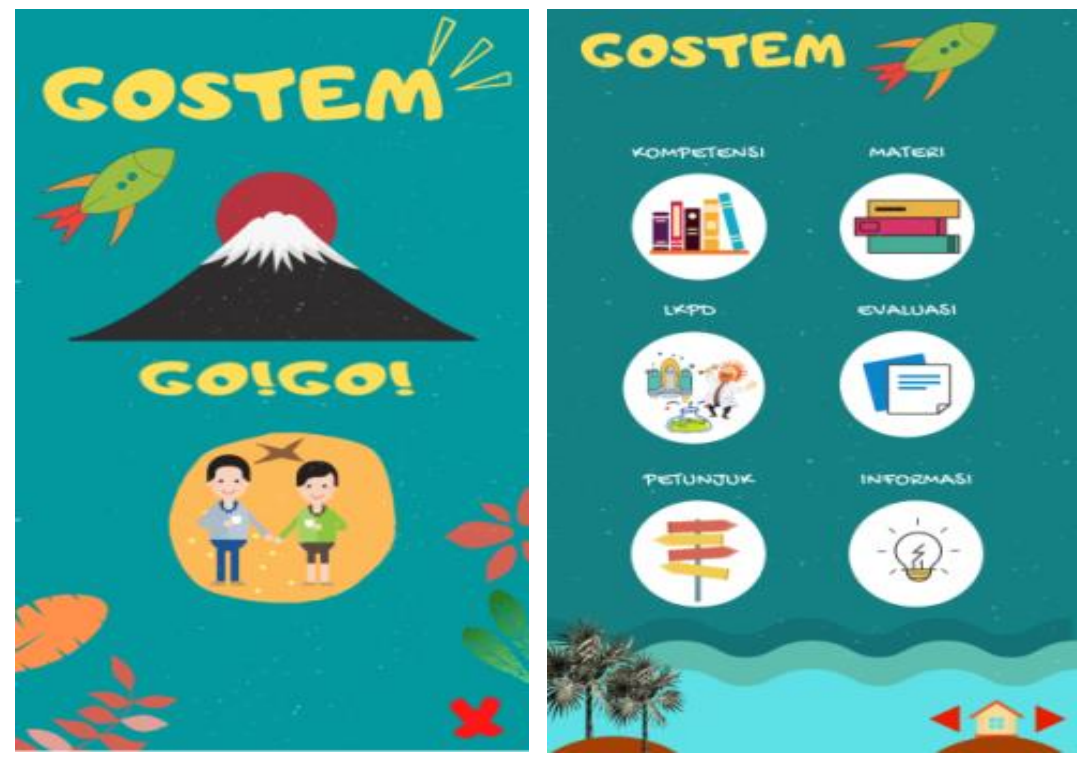

Gambar 3. Desain Awal Media Pembelajaran

\section{Tahap Formative Study (Tahap Evaluasi dan Revisi)}

Tahap formative study atau tahap evaluasi dalam penelitian ini bertujuan untuk memperbaiki 
prototype media pembelajaran yang dikembangkan oleh peneliti. Pada tahap ini peneliti menggunakan alur desain formative evaluation (Tessemer, 1993) yang terdiri dari empat tahap yaitu self evaluation, expert review, one-to-one, dan small group. Berikut adalah hasil dari masing-masing tahap evaluasi sebagi berikut:

\section{Self Evalution (Evaluasi Diri)}

Pada tahap ini peneliti dengan bantuan dosen pembimbing melakukan penilaian dan memeriksa kembali prototype 1 terhadap media pembelajaran yang dikembangkan. Setelah melakukan self evaluation peneliti memperbaiki kesalahan gambar dan tabel pada materi, pengetikan materi, pengetikan kuis, pengetikan Lembar Kerja Peserta Didik (LKPD) yang berisikan komponen-komponen pembelajaran STEM dengan model pembelajaran PjBL, warna tulisan, background, ikon, tombol, elemen yang tidak sesuai.

\section{Ekspert Review (Revisi Ahli)}

Tahap expert review ini merupakan tahap evaluasi dari hasil prototype 1 yang telah dikembangkan pada tahap self evaluation, penilaian dilakukan oleh ahli media dan ahli pendidikan yang dilakukan pada 13 juli sampai dengan 20 juli 2020 sebagai berikut:

\section{Ahli Media}

Ahli media disebut sebagai validator yang menilai dan memberikan komentar serta saran terkait aspek teknis (desain) dan aspek bahasa dari prototype 1 dengan mengisi lembar angket yang telah disusun peneliti. Penilaian oleh ahli media dilakukan untuk mengetahui apakah prototype 1 yang telah dikembangkan sudah memenuhi ktiteria media pembelajaran yang valid. Validasi dilakukan oleh tiga dosen matematika FKIP, hasil dari validasi ahli media dijadikan acuan untuk merevisi prototype 1 sehingga prototype 1 dinyatakan valid dan layak digunakan. Hasil penilaian validasi ahli media dapat dilihat pada Tabel 2.

Tabel 2. Rekapitulasi Nilai Ahli Media

\begin{tabular}{|c|c|c|c|}
\hline \multirow[t]{2}{*}{ No. } & \multirow[t]{2}{*}{ Rekapitulasi Nilai (\%) } & \multicolumn{2}{|c|}{ Aspek } \\
\hline & & Teknis (Desain) & Bahasa \\
\hline 1. & Ahli Media 1 & $77,89 \%$ & $80 \%$ \\
\hline 2. & Ahli Media 2 & $85,2 \%$ & $93,33 \%$ \\
\hline 3. & Ahli Media 3 & $83,15 \%$ & $73,33 \%$ \\
\hline & Rata-rata & $82,08 \%$ & $82,22 \%$ \\
\hline & Kategori & Sangat Valid & Sangat Valid \\
\hline
\end{tabular}

\section{Ahli Pendidikan}

Ahli pendidikan disebut sebagai validator yang menilai dan memberikan komentar serta saran terkait aspek isi yang terdiri dari aspek kualitas isi dan tujuan dan aspek instruksional (STEM) dari prototype 1 dengan mengisi lembar angket yang telah disusun peneliti. Penilaian oleh ahli pendidikan dilakukan untuk mengetahui apakah prototype 1 yang telah dikembangkan sudah memenuhi ktiteria media pembelajaran yang valid. Validasi dilakukan oleh tiga dosen FKIP Universitas Sultan Ageng Tirtayasa, hasil dari validasi ahli pendidikan dijadikan acuan untuk merevisi prototype 1 sehingga prototype 1 dinyatakan valid dan layak digunakan. Hasil penilaian validasi ahli pendidikan dapat dilihat pada Tabel 3. 
Pengembangan Media Pembelajaran Interaktif Android Matematika dengan Pendekatan STEM pada Materi Trigonometri, Almas Zati Hulwani, Heni Pujiastuti, Isna Rafianti

Tabel 3. Rekapitulasi Nilai Ahli Pendidikan

\begin{tabular}{|c|c|c|c|}
\hline \multirow{2}{*}{ No. } & Rekapitulasi Nilai (\%) & \multicolumn{2}{|c|}{ Aspek } \\
\cline { 3 - 4 } & & $\begin{array}{c}\text { Kualitas Isi dan Tujuan } \\
\text { (Kelayakan Isi) }\end{array}$ & $\begin{array}{c}\text { Instruksional (Kelayakan } \\
\text { STEM) }\end{array}$ \\
\hline 1. & Ahli Pendidikan 1 & $76 \%$ & $74 \%$ \\
\hline 2. & Ahli Pendidikan 2 & $84 \%$ & $86 \%$ \\
\hline 3. & Ahli Pendidikan 3 & $82,66 \%$ & $84 \%$ \\
\hline \multicolumn{2}{|c|}{ Rata-rata } & $80,88 \%$ & Sangat Valid \\
\hline \multicolumn{2}{|c|}{ Jumlah Rata-rata Kelayakan Isi } & Valid & Sangat Valid \\
\hline \multicolumn{2}{|c|}{ Kategori Jumlah Rata-rata Kelayakan Isi } & \multicolumn{2}{|c|}{} \\
\hline
\end{tabular}

\section{One-to-one}

Pada tahap one-to-one dilaksanakan pada tanggal 17 juli 2020 bersamaan dengan validasi ahli media dan ahli pendidikan, tahap one-to-one melibatkan tiga siswa. Siswa diberikan lembar angket untuk menilai dan memberikan komentar serta saran terkait aspek tampilan, aspek penyajian materi dan aspek manfaat dari prototype 1 media pembelajaran yang sedang dikembangkan. Tujuan dari tahap one-to-one adalah untuk menguji kepraktisan prototype 1 media pembelajaran yang dikembangkan. Hasil penilaian respon siswa pada tahap one-to-one dapat dilihat pada Tabel 4.

Tabel 4. Rekapitulasi Penilaian Respon Siswa Tahap One-to-one

\begin{tabular}{|c|c|c|c|c|}
\hline \multirow[t]{2}{*}{ No. } & \multirow[t]{2}{*}{ Rekapitulasi Nilai } & \multicolumn{3}{|c|}{ Aspek } \\
\hline & & Aspek Tampilan & Aspek Penyajian Materi & Aspek Manfaat \\
\hline 1. & M.Saefillahil.Abdat & $86,67 \%$ & $92,6 \%$ & $88,57 \%$ \\
\hline 2. & Diana & $93,3 \%$ & $88,4 \%$ & $82,85 \%$ \\
\hline 3. & Alif Ninho & $76,67 \%$ & $81 \%$ & $85,7 \%$ \\
\hline & Rata-rata & $85,5 \%$ & $87,3 \%$ & $85,7 \%$ \\
\hline & Kategori & Sangat Praktis & Sangat Praktis & Sangat Praktis \\
\hline
\end{tabular}

\section{Revisi Prototipe 1 Media Pembelajaran}

Revisi prototype 1 media pembelajaran yang dikembangkan berdasarkan komentar dan saran dari uji ahli media dan uji ahli pendidikan pada tahap expert review dan respon siswa pada tahap one-to-one. Setelah peneliti melakukan revisi pada prototype 1 maka menghasilkan prototype 2 . Salah satu hasil revisi prototype 1 media pembelajaran yang dikembangkan dapat dilihat pada Tabel 5.

Tabel 5. Revisi Prototype 1 Media Pembelajaran

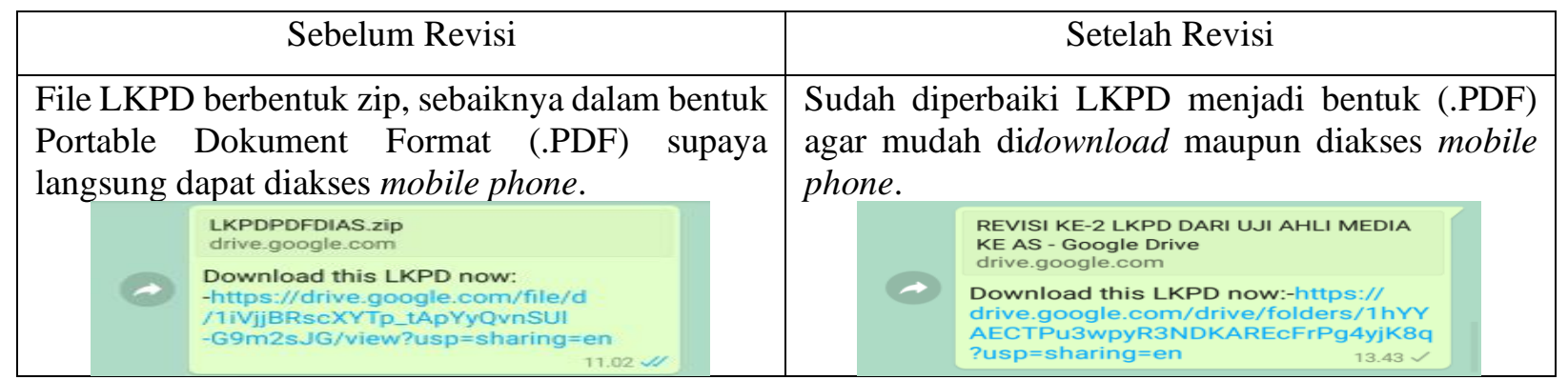




\section{Small Group}

Tahap small group dilaksanakan pada tanggal 27 juli 2020. Setelah peneliti melakukan revisi pada prototype 1 dan menghasilkan prototype 2, selanjutnya prototype 2 tersebut diberikan kepada enam siswa SMA Negeri 2 Kota Serang yang telah mempelajari materi trigonometri untuk melihat kepraktisan media pembelajaran yang dikembangkan. Siswa diberikan lembar angket untuk menilai dan memberikan komentar serta saran terkait aspek tampilan, aspek penyajian materi dan aspek manfaat dari prototype 2 media pembelajaran yang dikembangkan. Hasil penilaian respon siswa pada tahap small group dapat dilihat pada Tabel 6.

Tabel 6. Rekapitulasi Penilaian Respon Siswa Tahap Small Group

\begin{tabular}{|c|c|c|c|c|}
\hline \multirow[t]{2}{*}{ No. } & \multirow[t]{2}{*}{ Rekapitulasi Nilai } & \multicolumn{3}{|c|}{ Aspek } \\
\hline & & Aspek Tampilan & Aspek Penyaiian Materi & Aspek Manfaat \\
\hline 1. & RK & $90 \%$ & $86,3 \%$ & $85,7 \%$ \\
\hline 2. & EA & $93,33 \%$ & $93,68 \%$ & $88,57 \%$ \\
\hline 3. & $\mathrm{AB}$ & $86,67 \%$ & $86,3 \%$ & $94,28 \%$ \\
\hline 4. & RPS & $90 \%$ & $82,1 \%$ & $85,7 \%$ \\
\hline 5. & HF & $86,67 \%$ & $80 \%$ & $80 \%$ \\
\hline 6. & NA & $93,33 \%$ & $89,47 \%$ & $85,7 \%$ \\
\hline & Rata-rata & $90 \%$ & $86,3 \%$ & $86,65 \%$ \\
\hline & Kategori & Sangat Praktis & Sangat Praktis & Sangat Praktis \\
\hline
\end{tabular}

\section{Revisi Prototype 2 Media Pembelajaran}

Revisi prototype 2 media pembelajaran yang dikembangkan berdasarkan komentar dan saran dari respon siswa pada tahap small group. Setelah peneliti melakukan revisi pada prototype 2 maka menghasilkan prototype 3 . Salah satu hasil revisi prototype 2 media pembelajaran yang dikembangkan dapat dilihat pada Tabel 7.

Tabel 7. Revisi Prototype 2 Media Pembelajaran

\begin{tabular}{|c|c|c|c|}
\hline \multicolumn{2}{|r|}{ Sebelum Revisi } & \multicolumn{2}{|c|}{ Setelah Revisi } \\
\hline 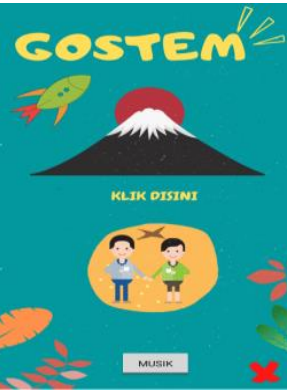 & $\begin{array}{l}\text { Materi yang di berikan sangat } \\
\text { mudah dipahami dan sangat } \\
\text { menarik membuat semangat belajar } \\
\text { meningkat. Tombol saat masuk } \\
\text { aplikasi sedikit kurang jelas. }\end{array}$ & 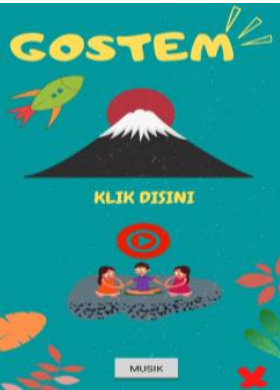 & $\begin{array}{l}\text { Saran diterima dan } \\
\text { sudah diperbaiki. }\end{array}$ \\
\hline
\end{tabular}

\section{Field Test}

Tahap field test dilaksanakan pada tanggal 30 juli 2020. Setelah peneliti melakukan revisi pada prototype 2 dan menghasilkan prototype 3 yang valid dan praktis selanjutnya prototype 3 tersebut diberikan kepada subjek penelitian yaitu 35 siswa kelas X MIPA 7 SMA Negeri 2 Kota Serang yang telah mempelajari materi trigonometri untuk melihat efek potensial dari media pembelajaran yang dikembangkan oleh peneliti 
Pengembangan Media Pembelajaran Interaktif Android Matematika dengan Pendekatan STEM pada Materi Trigonometri, Almas Zati Hulwani, Heni Pujiastuti, Isna Rafianti

terhadap respon siswa. Siswa diberikan lembar angket untuk menilai dan memberikan komentar terkait aspek tampilan, aspek penyajian materi dan aspek manfaat dari prototype 3 media pembelajaran yang dikembangkan. Hasil penilaian respon siswa pada tahap field test dapat dilihat pada Tabel 8.

Tabel 8. Rekapitulasi Penilaian Respon Siswa Tahap Field Test

\begin{tabular}{|c|l|c|c|}
\hline No. & \multicolumn{1}{|c|}{ Aspek } & Rata-rata Presentase Tiap Aspek & Keterangan \\
\hline 1. & Aspek Tampilan & $96,76 \%$ & Sangat Efektif \\
\hline 2. & Aspek Penyajian Materi & $95,63 \%$ & Sangat Efektif \\
\hline 3. & Aspek Manfaat & $96,16 \%$ & Sangat Efektif \\
\hline \multicolumn{2}{|c|}{ Jumlah Rata-rata Semua Aspek } & $96,1 \%$ & Sangat Efektif \\
\hline
\end{tabular}

\section{Diskusi}

Tahap preliminary study terdiri dari dua tahap yaitu tahap perencanaan dan tahap pengembangan. Tahap perencanaan dilakukan pada bulan Januari 2020, peneliti melakukan analisis kebutuhan dengan menganalisis kurikulum 2013 mata pelajaran matematika wajib kelas X SMA untuk mengidentifikasi kompetensi dasar, capaian pembelajaran, indikator pembelajaran dan materi yang dimuat pada media pembelajaran yang dikembangkan. Murti (2013) penerapan kurikulum 2013 yang oleh pemerintah diharapkan dapat membantu dalam menyiapkan keterampilan siswa dalam menghadapi perkembangan abad 21 seperti kemampuan berpikir kritis, kemampuan berpikir kreatif dan kemampuan berkomunikasi. Berdasarkan hasil analisis terhadap materi trigonometri terdapat beberapa sub materi yang dipelajari terhadap materi trigonometri yaitu perbandingan trigonometri pada segitiga siku-siku, perbandingan trigonometri pada segitiga siku-siku untuk sudut istimewa dan aturan sinus dan cosinus yang mana sub materi yang dikembangkan tersebut telah mengandung unsur STEM.

Tahap pengembangan dilakukan setelah tahap perencanaan selesai dilakukan, tahap ini dilakukan pada bulan Februari 2020 sampai Juni 2020. Tahapan ini terdiri dari tiga tahap yaitu: tahap pengembangan topik yaitu dengan mengembangkan pokok bahasan trigonometri bisa mengaitkannya dengan pendekatan STEM berdasarkan indikator dan tujuan pembelajaran yang dicapai; tahap penyusunan draft dengan menentukan urutan pokok bahasan dan komponen-komponen yang dituliskan atau desain kedalam prototype media pembelajaran diantaranya yaitu kompetensi yang terdiri dari kompetensi inti, kompetensi dasar dan indikator dan tujuan pembelajaran. Trigonometri merupakan ilmu yang mempelajari tentang unsur-unsur segitiga sebagai objek kajian keilmuan (Rusgianto, 2007). Materi trigonometri yang terdapat beberapa sub materi yang dipelajari terhadap materi trigonometri yaitu perbandingan trigonometri pada segitiga siku-siku, perbandingan trigonometri pada segitiga siku-siku untuk sudut istimewa dan aturan sinus dan cosinus. LKPD yang berisikan komponen-komponen pembelajaran STEM-PjBL terdiri dari tiga LKPD sesuai dengan sub materi dimana menurut Billstein \& Williamson (2007) kolaborasi proses tersebut disusun pada langkah-langkah yaitu setting the stage, exploration, key concept, practice and application exercise. Terdapat evaluasi berupa kuis, petujuk penggunaan media pembelajaran berupa Android Studio, dan 
informasi yang terdiri dari profil dan penjelasan STEM; dan tahap produksi prototype peneliti merancang hasil desain background, elemen atau ikon, tombol sesuai dengan materi trigonometri dengan pendekatan STEM, teks yang rapih dan berwarna, tabel yang diatur dan disesuaikan dengan teks sehingga tampilan setiap halaman tersusun dengan rapih dan menarik, Lembar Kerja Peserta Didik (LKPD) yang berisikan komponen-komponen pembelajaran STEM-PjBL, soal kuis pada media pembelajaran yang dikembangkan pada Android Studio agar relevan dengan pelaksanaan pembelajaran STEM. Konsep materi dan LKPD dengan pendekatan STEM-PjBL yang dikembangkan, yaitu: Science hal-hal yang berkaitan dengan pengetahuan alam, fenomena alam atau kehidupan sehari-hari. Masalah yang diangkat berkaitan dengan konsep kesebangunan pada segitiga siku-siku, kecepatan, gerak lurus beraturan, fenomena alam gunung meletus serta isu-isu politik; Technology merupakan salah satu sarana yang digunakan untuk menyelesaikan masalah yang diberikan. Pada kegiatan ini teknologi yang digunakan adalah Android Studio dan pesawat sederhana; Engineering merupakan bagian dari proses penyelesaian masalah. Proses yang dilakukan mengacu pada proses EDP (Engineering Design Process) yang melibatkan teknik sipil dan arsitektur, bekerjasama, dan melakukan perhitungan. Kemampuan ini melatih kemampuan siswa untuk memecahkan masalah dalam dunia nyata; Mathematics mengambil materi trigonometri, materi tersebut merupakan pembangunan daya pikir siswa dalam menyelesaikan masalah yang diberikan.

Tahap formative study dilakukan pada bulan Juli 2020, tahap ini terdiri dari empat tahap yaitu self evaluation, expert review, one-to-one, dan small group. Pada tahap self evaluation peneliti dengan bantuan dosen pembimbing melakukan penilaian dan memeriksa kembali prototype 1 terhadap media pembelajaran yang dikembangkan. Setelah memperbaiki self evaluation, selanjutnya peneliti ke tahap expert review.

Tahap expert review ini dilakukan dari 13 juli sampai dengan 20 juli 2020. Prototipe 1 media pembelajaran berupa Android Studio ini divalidasi oleh tiga orang dosen ahli media dan tiga orang dosen ahli pendidikan. Hasil penilaian kevalidan teknis (desain) dari media pembelajaran ini adalah sebesar $82,08 \%$. Beberapa saran dari validator pada validasi teknis (desain) yaitu: Tombol menuju Home yaitu Go! Go! lebih baik diganti; Lebih menyesuaikan warna yang lembut dimata dan perbaiki suara. Hasil penilaian kevalidan bahasa dari media pembelajaran ini adalah sebesar $82,22 \%$. Beberapa saran dari validator pada validasi bahasa yaitu: Perbaiki redaksi yang kurang sesuai; Gunakan equation pada symbol matematika; Aspek font dioptimalkan. Hasil yang didapatkan dari kevalidan isi yang terdiri dari penilaian aspek kualitas isi dan tujuan (isi) dan instruksional (kelayakan STEM) didapatkan sebesar 81,1\%. Beberapa saran dari validator pada validasi isi untuk perbaikan yaitu: Dalam media ini, pendekatan STEMnya harus diperjelas lagi, matematika dikaitkan dengan apa saja? serta alat, produk, contoh bentuk integrasi matematika dengan ilmu lainnya perlu dipertegas; Indikator STEM dalam pembelajaran di perjelas, interaktif lebih di kembangkan tidak hanya di kuis tapi seluruh komponen pembelajaran; LKPD dikembangkan menjadi interaktif; File LKPD berbentuk zip, sebaiknya dalam bentuk Portable Dokument Format (.PDF) supaya langsung dapat diakses mobile phone. Berdasarkan validator uji ahli media dan uji ahli pendidikan menyatakan bahwa prototype I telah dinyatakan valid dan layak diujicobakan dengan revisi sesuai saran.

Tahap one-to-one dilakukan pada tanggal 17 juli 2020 dengan tiga siswa di SMAN 2 Kota Serang 
yang telah mengikuti mata pelajaran matematika materi trigonometri. Tahapan ini bertujuan untuk menguji kepraktisan prototype 1 yang telah dibuat oleh peneliti dari sudut pandang pengguna melalui pengisian lembar angket respon siswa terhadap penggunaan prototype 1. Nilai kepraktisan penggunaan prototype 1 semua aspek dengan rata-rata $86 \%$ dengan kategori sangat praktis, sedangkan masing-masing pada aspek tampilan, aspek penyajian materi, dan aspek manfaat berturut-turut adalah 85,5\%, 87,3\%, dan 85,7\% dengan kategori masing-masing aspek sangat praktis. Komentar dan saran hasil one-to-one selanjutnya digunakan untuk perbaikan terhadap prototype 1 sehingga dihasilkan prototype 2 yang valid dan praktis. Tahap small group dilaksanakan pada tanggal 27 juli 2020. Setelah peneliti melakukan revisi pada prototype 1 dan menghasilkan prototype 2 , selanjutnya prototype 2 tersebut diberikan kepada enam siswa SMA Negeri 2 Kota Serang yang telah mempelajari materi trigonometri untuk melihat kepraktisan media pembelajaran yang dikembangkan. Nilai kepraktisan penggunaan prototype 2 semua aspek dengan rata-rata 87,65\% dengan kategori sangat praktis, sedangkan pada aspek tampilan, aspek penyajian materi, dan aspek manfaat berturut-turut adalah 90\%, 86,3\%, dan 86,65\% dengan kategori masing-masing aspek sangat praktis. Komentar dan saran hasil small group selanjutnya digunakan untuk perbaikan terhadap prototype 2 sehingga dihasilkan prototype 3 yang valid dan praktis.

Setelah tahap small group dilakukan, tahap selanjutnya yaitu tahap field test. Tahap small group dilakukan pada tanggal 30 juli 2020 dengan subjek 35 siswa kelas X MIPA 7 SMAN 2 Kota Serang yang telah mengikuti mata pelajaran matematika materi trigonometri. Setelah diperoleh prototype 3 yang valid dan praktis maka diujicoba field test untuk melihat efek potensial terhadap respon siswa. Nilai keefektifan penggunaan prototype 3 semua aspek dengan rata-rata 96,1\% dengan kategori sangat efektif, sedangkan pada aspek tampilan, aspek penyajian materi, dan aspek manfaat berturut-turut adalah 96,76\%, 95,63\%, dan 96,16\% dengan kategori masing-masing aspek sangat efektif dan terdapat komentar dari 35 siswa.

\section{KESIMPULAN}

Penelitian pengembangan ini menghasilkan media pembelajaran interaktif android matematika dengan pendekatan STEM pada materi trigonometri yang valid, praktis dan memiliki efek potensial terhadap respon siswa dalam kegiatan pembelajaran matematika. Validitas media pembelajaran diperoleh dari pengisian angket para ahli media dan ahli pendidikan pada tahap expert review, kepraktisan yang diperoleh dari pengisian angket tahap one-to-one dan small group, dan efek potensial yang didapat dari pengisian angket respon siswa pada tahap field test. Jadi media pembelajaran interaktif android matematika dengan pendekatan STEM pada materi trigonometri yang dikembangkan layak digunakan dalam kegiatan pembelajaran matematika karena telah memenuhi kategori kevalidan yang sangat valid, kepraktisan yang sangat praktis dan memiliki efek potensial terhadap respon siswa yang sangat efektif.

\section{UCAPAN TERIMA KASIH}

Peneliti mengucapkan rasa syukur kepada Allah SWT karena diberikan kesehatan dan kemudahan dalam menyelesaikan artikel ini. Terimakasih kami ucapkan kepada Bapak/Ibu validator, Kepala Sekolah, 
dewan guru dan siswa-siswi kelas X SMA Negeri 2 Kota Serang yang sudah memberikan dukungan, izin dan berpartisipasi dalam terlaksanannya penelitian ini. Serta terimakasih kepada keluarga dan rekan sejawat yang selalu memberikan dukungan.

\section{REFERENSI}

Akhmadan, W. (2017). Pengembangan Bahan Ajar Materi Garis dan Sudut Menggunakan Macromedia Flash dan Moodle Kelas VII Sekolah Menengah Pertama. Jurnal Gantang, 2(1). https://doi.org/10.31629/jg.v2i1.62

Billstein, R., \& Williamson, J. (2007). Middle School MATH THEMATICS The STEM Project (Edition 3). Evanston: McDougal Littell.

Bybee, R. (2010). Advancing STEM Education: A 2020 Vision. Technology and Engineering Teacher.

Erlinawati, C. E., Bektiarso, S., \& Maryani. (2019). Model Pembelajaran Project Based Learning Berbasis STEM Pada Pembelajaran Fisika. Seminar Nasional Pendidikan Fisika 2019, 4(1), 1-4.

Herawati, E. (2017). Upaya Meningkatkan Motivasi Dan Hasil Belajar Siswa Menggunakan Media Pembelajaran Kartu Domino Matematika Pada Materi Pangkat Tak Sebenarnya Dan Bentuk Akar Kelas IX SMP Negeri Unggulan Sindang Kabupaten Indramayu. JNPM (Jurnal Nasional Pendidikan Matematika), 1(1), 66. https://doi.org/10.33603/jnpm.v1i1.254

Juraman, S. R. (2014). Pemanfaatan Smartphone Android Oleh Mahasiswa llmu Komunikasi Dalam Mengakses Informasi Edukatif. Journal Volume III. No.1. Tahun 2014, III(1). Retrieved from https://ejournal.unsrat.ac.id/index.php/actadiurna/article/viewFile/4493/4022

Kemendikbud. (2017). Buku Guru Ilmu Pengetahuan Alam. Jakarta: Kementerian Pendidikan dan Kebudayaan.

Laboy-Rush, D. (2010). Integrated STEM Education through Project-Based Learning. New York: Learning.com.

Lu 'mu. (2017). Learning Media Of Applications Design Based Android Mobile Smartphone. International Journal of Applied Engineering Research ISSN, 12(17). Retrieved from http://www.ripublication.com Maiyana, E. (2018). Pemanfaatan Android Dalam Perancangan Aplikasi Kumpulan Doa. Jurnal Sains Dan Informatika, 4(1), 54-65. https://doi.org/10.22216/jsi.v4i1.3409

May, V., \& Courtney, S. (2016). Developing Meaning in Trigonometry. Illinois Mathematics Teacher, 63(1), 25-33.

Murti, K. E. (2013). Pendidikan Abad 21 Dan Implementasinya Pada Pembelajaran Di Sekolah Menengah Kejuruan (SMK) Untuk Paket Keahlian Desain Interior. Artikel Kurikulum 2013 SMK, 1-23.

Riduwan. (2013). Skala Pengukuran Variabel-variabel Penelitian. Bandung: Alfabeta.

Rusgianto. (2007). TRIGONOMETRI Membangun Kekuatan Konstruksi Kognitif. Yogyakarta: Grafika Indah.

Sanjaya, W. (2010). Strategi Pembelajaran Berorientasi Standar Proses Pendidikan. Jakarta: Kencana Prenada Media Group. 
Pengembangan Media Pembelajaran Interaktif Android Matematika dengan Pendekatan STEM pada Materi Trigonometri, Almas Zati Hulwani, Heni Pujiastuti, Isna Rafianti

Tessemer, M. (1993). Planning and Conducting Formative Evaluations. London: Kogan Page.

Widoyoko, E. P. (2016). Teknik Penyusunan Instrumen Penelitian. Yogyakarta: Pustaka Pelajar.

Zakiy, M. A. Z., Muhammad, S., \& Farida. (2018). Pengembangan Media Android dalam Pembelajaran Matematika. TRIPLE S:Jourals of Mathematics Education, 1(2), 87-96.

Zulkardi. (2006). Formative Evaluation: What, Why, When and How. Retrieved from https://www.oocities.org/zulkardi/books.html 